\title{
Masculinities, Violence and Self-defence in Swedish Supreme Court Cases*
}

\section{Zusammenfassung}

Der vorliegende Artikel beschäftigt sich mit dem Zusammenspiel von Männlichkeitsnormen, wie sie sowohl im Präzedenzrecht des schwedischen Obersten Gerichtshofs als auch im juristischen Konstrukt des Rechts auf Selbstverteidigung im schwedischen Strafrecht zum Ausdruck kommen und wie dieses Zusammenspiel zu einer Normalisierung männlicher Gewalthandlungen beiträgt. Anhand der vier Fälle, die in den vergangenen zwanzig Jahren vor dem schwedischen Obersten Gerichtshof verhandelt wurden, wird eine Diskursanalyse durchgeführt, die sich insbesondere mit dem Recht auf Selbstverteidigung im Kontext von Gewalt zwischen Männern befasst. Die theoretischen Ausgangspunkte dafür sind dabei zum einen, dass Männlichkeiten als relational, divers und hierarchisch beschrieben werden können und Geschlecht als Verfahren zur Erzeugung sozialer Ordnungspraktiken dient, und zweitens, dass Gewalt zur Ausführung oder Erreichung von Männlichkeit dient, auch wenn Männlichkeiten nicht alle gleich gewaltgeprägt sind. Da die Rechtsvorschriften für Gewaltverbrechen in den meisten Fällen auf Gewalttaten von Männern angewendet werden, ist die Beziehung zwischen Männlichkeiten und Gewalt vor allem in der Debatte über Gewalt und Recht von entscheidender Bedeutung Wie die Auswertung dieser Untersuchung zeigt, existiert ein Spielraum, in dem sich Geschlechternormen und Geschlechterbilder auf Urteile im Strafrechtssystem auswirken, während im Gegenzug Strafrecht und Strafrechtssystem Geschlechternormen beeinflussen. Durch diese Wechselwirkung tragen das Strafrecht und dessen Anwendung zur Normalisierung männlicher Gewalthandlungen bei. Dabei ist es wichtig, die Kreuzungspunkte von Geschlecht und anderen Machtstrukturen ebenso zu betrachten wie die Ausprägung von Gewalt und Recht in ihren jeweiligen Kontexten. Im Abschluss steht das Fazit, dass die Untersuchung der Beziehungen zwischen Männlichkeiten, Gewalt und Recht die Ergebnisoffenheit des Rechts offenbart. Zwar bringt diese Ergebnisoffenheit Unsicherheit und Unwägbarkeit mit sich, bildet aber auch ein Terrain für Auseinandersetzung und Wandel.

\section{Résumé}

Cet article traite des interactions entre les normes de masculinité énoncées dans la jurisprudence de la Cour Suprême de Suède et l'interprétation juridique du droit à la

* Susanna Eriksson is a doctoral student in criminal law at Umeå Forum for Studies on Law and Society and the Graduate School of Gender Studies, Umeå University. Her dissertation project has the working title "Gender, crime and power - discourses in criminal law" and concerns discourses on gender and criminality in the Swedish criminal justice system, specifically regarding defendants and violent crime (assault). 
légitime défense dans la législation pénale suédoise, ainsi que la manière dont ces interactions contribuent à la normalisation des actes de violence des hommes. Une analyse du discours est réalisée sur les quatre affaires des vingt dernières années tranchées par la Cour Suprême qui portent spécifiquement sur le droit à la légitime défense dans un contexte de violence entre hommes. Les points de départ théoriques sont, tout d'abord, que les masculinités sont relationnelles, variées et hiérarchiques, et que le genre est une manière d'ordonner les usages sociaux. Deuxièmement, la violence est une manière d'exercer ou d'atteindre la masculinité, bien que les masculinités se rapportent à la violence de différentes manières. Puisque la législation relative aux crimes violents s'applique à la majorité des actes de violence des hommes, la relation entre les masculinités et la violence est d'une importance cruciale lorsque l'on évoque la violence et le droit. Les conclusions de l'analyse sont qu'il existe un espace où les normes et idéaux de genres ont un effet sur les décisions du système de la justice pénale, tandis que le droit pénal et le système de justice pénale ont un effet sur les normes de genre. Au travers de cette interaction, le droit pénal et son application contribuent à la normalisation des actes de violence des hommes. L'importance de considérer la manière dont les genres interagissent avec les autres structures de pouvoir est mise en évidence, et la violence et le droit envisagés dans leur contexte. En conclusion, l'analyse des relations entre les masculinités, la violence et le droit révèle l'ouverture du droit. Si cette ouverture apporte incertitude et imprévisibilité, elle fait également du droit un terrain d'affrontement et de changement.

\section{A. Introduction}

When trying to understand the relationship between law and violence, it is important to take masculinities and how they relate to law as well as violence into account. The absolute majority of violent crimes in Sweden are committed by men and this is also the case throughout Europe. ${ }^{1}$ This makes the link between masculinities and violence apparent and also highlights the importance of this relation when it comes to law. Because if the absolute majority of violent crimes are committed by men it means that the absolute majority of the defendants in criminal trials regarding violent crime are also men. The legislation on violent crimes is therefore in most cases applied on men's violent acts.

The aim of this article is to explore and discuss the interaction between masculinity norms expressed in case-law from the Swedish Supreme Court and the legal construction of the right to self-defence in Swedish criminal law and how this interaction contributes to the normalisation of men's violent acts.

This article is based on a discourse analysis of the four cases from the Swedish Supreme Court of the last twenty years that deals specifically with questions regarding the right to self-defence when it comes to man-to-man violence. These cases are of vital importance when it comes to the interpretation and application of the rules of self-de-

1 In Sweden, according to criminal statistics $86 \%$ of those convicted of assault were men (National Council of Crime Prevention, Kriminalstatistik 2012, table 4.3, 178). In Europe it spans between $79,2 \%$ to $100 \%$ according to Scambor/Wojnicka/Bergmann (eds.), The Role of Men in Gender Equality - European Strategies and Insights, prepared for European Commission, DG Justice - Unit D2 Gender Equality, 2012, 107. 
fence, which makes them particularly interesting from a discourse analysis point-ofview. By doing discourse analysis on these cases, I can highlight the interaction between masculinity norms and legal norms, as well as challenge that which appears natural, neutral and taken-for-granted. ${ }^{2}$ The analysed texts from the cases are the written judgments, not transcripts from the main hearings. This means that it is the courts' account for, and interpretation of, what was said during the main hearing as well as their own grounds for their verdict which is the object of study. The cases will be presented in more detail below.

\section{The Right to Self-defence in Swedish Criminal Law}

The right to self-defence in Swedish criminal law is found in chapter 24 section 1 of the Penal Code. ${ }^{3}$ It states that an act committed by a person in self-defence is a crime only if it is clearly unjustifiable, with regards taken to the nature of the aggression, the importance of its object and the circumstances in general. A right to self-defence exists in four different kinds of situations:

1. Against an initiated or imminent criminal attack on a person or property.

2. Against a person who violently or by the threat of violence or in some other way obstructs the repossession of property when caught in the act.

3. Against a person who has unlawfully forced or is attempting to force entry into a room, house, yard or vessel.

4. Against a person who refuses to leave a dwelling when ordered to do so.

As the cases analysed in this paper only concerns the first two situations (especially the first one) I will not elaborate further on situations three and four.

According to legislative preparatory works, which has been confirmed in the caselaw of the Supreme Court, a wide margin of appreciation is to be granted the defendant as regards his or her assessment of the situation, for example when it comes to finding alternatives to act in self-defence (such as being able to get away from the assault). ${ }^{4}$ There is however no absolute duty to leave even if it would be possible, although it will be taken into consideration when the court assesses the justifiability of the defendant's actions. ${ }^{5}$ That a criminal attack is imminent means that there is a looming danger of such an attack. ${ }^{6}$ The circumstances of the situation are decisive in assessing whether or not a criminal attack is imminent.

2 For further readings on discourse analysis and criminal law, see Burman, Beyond Constructed Boundaries in Criminal Law Discourse, in: Gunnarsson/Svensson/Davies (eds.), Exploiting the Limits of Law: Swedish Feminism and the Challenge to Pessimism, Ashgate, Aldershot 2007.

3 In Swedish: "brottsbalken", an official translation from Swedish to English is to be found in the Ministry Publication Series 1999:36.

4 Government bill (prop.) 1993/94:130, 69. See also NJA 2005, 237 (245).

5 This follows from a number of published cases from the Supreme Court: NJA 1969, 425, NJA 1970, 58 among others. See also Leijonhufvud/Wennberg, Straffansvar, $8^{\text {th }}$ ed., Norstedts Juridik, Stockholm 2009, 87.

6 Swedish Government Official Report (SOU) 1953:14, 395. In this report the Criminal Law Committee gave as an example of when an attack is imminent the scenario that a captain on a ship found out that his crew was planning to kill him when reaching a certain location, would have the right to act in self-defence against the crew members. 
Regarding the second situation, in which a right to act in self-defence exists, the timing of the act is of great importance. As stated above, it can only be an issue of self-defence if the one who wants to repossess his or her property has caught the obstructing one in the act. There can only be a brief amount of time between the dispossession and the selfdefence act. This further means that a right to act in self-defence does not exist in every situation, in which a person according to Swedish law can repossess his or her lost property. $^{7}$

When assessing the justifiability of the defendant's actions, the court must take the nature of the aggression, the importance of its object and the circumstances in general into account. This means that the violence the defendant used in self-defence can't be disproportionate in relation to the nature of the attack, and what is permissible to do in self-defence also depends on the value or importance of what is attacked. ${ }^{8}$ A person who acts in self-defence can do more if her or his life is in danger due to the attack than if someone is about to destroy their property. As regards the circumstances in general, the preparatory works specifically mentions the possibilities of avoiding the attack by calling for help and also the traits of the attacked. As an example it is mentioned that a physically weaker person can be allowed the use of some sort of weapon in self-defence in cases where a physically stronger person could not be allowed to do so. ${ }^{9}$

If the actions of the defendant are deemed clearly unjustifiable, there is still a possibility for letting the defendant go free from responsibility. Excessive self-defence is regulated in chapter 24 section 6 of the Penal Code. According to preparatory works, as well as case-law, the assessment of whether or not it is excessive self-defence is done with regards taken both to the defendant's individual capabilities to handle the situation (internal circumstances) as well as external circumstances. ${ }^{10}$ Examples of internal circumstances are particularly fear, shock, intoxication. ${ }^{11}$ External circumstances are the time and place of the attack, the traits of the attacker (physically stronger, intoxication and so on) and if the attack was sudden or unexpected. ${ }^{12}$

7 Government bill 1993/94:130, 29.

8 Government bill 1962:10, 327.

9 Government bill 1993/94:130, 31-32.

10 Government bill 1993/94:130, 45-46.

11 NJA 1994, 48 (58).

12 NJA 2005, 237 (248). 


\section{B. Masculinities and Violence}

There is a lot of research done on masculinities in general as well as on masculinities and violence. ${ }^{13}$ It is not easy to define masculinity, since there is no singular definition of masculinity just as there is no singular definition of gender. For the purpose of this article I choose to use Connell's attempt to define masculinity:

' 'Masculinity', to the extent the term can be briefly defined at all, is simultaneously a place in gender relations, the practices through which men and women engage that place in gender, and the effects of these practices in bodily experience, personality and culture." 14

The keyword is "relations". According to Connell, ${ }^{15}$ gender is relational. Masculinity can only exist in relation to something else; femininity. In the same way, different kinds of masculinities also exist in relation to other kinds of masculinities. ${ }^{16}$ This means that gender is never fixed but always open to change just because it is shaped by social practices and relations. However, gender isn't just shaped by social practices but, according to Connell, also orders social practices (although it is not the only way these practices are ordered) through power relations, production relations and relations of desire. ${ }^{17}$ Law as a social practice and institution is therefore shaped by gender and gender relations but is also shaping gender and gender relations. A relational definition of masculinities and Connell's theory of the social organization of masculinities opens up for an analysis and discussion on a structural level. This suits the purpose of the article; to discuss how law relates to masculinities and violence in the context of self-defence on a structural level.

Different masculinities relate to each other. These relations are shaped by e.g. ethnicity, class, sexuality, gender identity or expression, age and dis/ability. ${ }^{18}$ Masculinities are in other words positioned in hierarchical relations to each other and therefore relate differently to various practices and phenomena, such as violence. In 'Masculinities and Crime' Messerschmidt makes the same point, that while all men and all kinds of masculinities relate to violence in one way or another, they do not do so in the same way. ${ }^{19}$ Violence can be seen as a way of performing or achieving masculinity, a way of

13 For a historical overview of masculinity studies, see Connell, Masculinities, $2^{\text {nd }}$ ed., Polity Press, Cambridge 2005. For an overview of examples of recent research on masculinities and crime, see Messerschmidt, Crime as structured action: doing masculinities, race, class, sexuality, and crime, $2^{\text {nd }}$ ed., Rowman \& Littlefield, Lanham 2014. For an overview of research on masculinities and law, see Collier, Men, Law and Gender: Essays on the 'Man' of Law, Routledge, Abingdon 2010; and for further examples of research on masculinities and law, see Dowd, The Man Question: Male Subordination and Privilege, New York University Press, New York 2010, Cooper/McGinley (eds.), Masculinities and the law: a multi-dimensional approach, New York University Press, New York 2012.

14 Connell, 71.

15 Connell, 68.

16 Dowd, 28.

17 Connell, 71-76.

18 Cooper/McGinley (eds.), 5.

19 Messerschmidt, Masculinities and Crime: Critique and Reconceptualization of Theory, Rowman \& Littlefield, Lanham 1993. 
proving yourself a man. ${ }^{20}$ Whether glorified (the knight in shining armour, the boxing superstar) or abhorred (a terrorist, a serial-killer), violence is intimately linked with men and masculinities. At a structural level, men's violence against women is a tool for upholding the unequal power relations between men and women but men's violence against other men is also a tool for upholding unequal power relations among men. ${ }^{21}$ Different masculinity norms and ideals enable and condone men's violence.

When discussing relations between masculinities and violence it is important to remember that it is men who actually apply violence, not masculinities as such. ${ }^{22}$ Men's violent acts are part of upholding gendered power structures. ${ }^{23}$ This is why this article explicitly focuses on masculinities and men's violent acts in a self-defence context. From a criminal law point-of-view, a focus on men's violent acts high-lights men's responsibility for those acts. It also enables scrutinising how criminal law, and the application of it, assesses men's violent acts. ${ }^{24}$ Combined with an understanding of gender and masculinities as diverse, relational, and hierarchical and a way of ordering social practices, this enables me to analyse how masculinity norms and ideals play a role in the criminal justice system. In the end, this becomes a question of how criminal law and the criminal justice system take part in shaping gender relations and gender norms, and also how criminal law and the criminal justice system contribute to the normalisation of men's violence.

With these theoretical starting points, I move on to an analysis of the four cases from the Swedish Supreme Court, and in this analysis I will use examples of research on men, masculinities, violence and law.

\section{B. Masculinities and Self-Defence in the Case-Law of the Swedish Supreme Court}

The analysis of the cases will be presented in three themes, following the discourses I have identified in the written judgments. Each theme will begin with an extensive review of the case in question, except the second theme ("Should I stay or should I go?") in which two cases are presented and analysed. ${ }^{25}$

20 Bibbings, Boys Will Be Boys: Masculinity and Offences Against the Person, in: Nicholson/ Bibbings (eds.), Feminist Perspectives on Criminal Law, Cavendish Publishing, London 2000, 234.

21 Connell, 83.

22 Hearn, The Violences of Men, SAGE Publications, London 1998, 34-37.

23 Hearn, 32.

24 For an example of such scrutiny, see Bibbings, 237-243.

25 Quotes from the written judgments that exemplify the discourses are presented, and the translation of these quotes has been carefully done by me. The responsibility for any flaws in the translation is therefore entirely mine. 


\section{A natural thing to do}

In the first case,${ }^{26}$ the defendant $(\mathrm{H})$ woke up suddenly in the middle of the night because he heard the sound of a window being crashed. According to his testimony as summarized by the court he "just knew" that it was the window of his brand new car. When he got out to his car he saw that this was the case and decided to find the one (or ones) who did it and, as a precaution, took a diver's knife from the trunk of his car. After a short while, he saw a person $(\mathrm{J})$ who started to run when he saw that $\mathrm{H}$ had seen him. $\mathrm{H}$ caught up with $J$ and during the turmoil that followed in which the defendant managed to subdue $\mathrm{J}$, he also unintentionally injured Js face with the knife. J admitted to having broken into Hs car together with another person. That person had taken the CD-player while $\mathrm{J}$ had some of Hs CDs with him. H, using his knife, forced J to go with him to a telephone booth from which $\mathrm{H}$ called the police.

The city court found that the evidence in the case did not support that $\mathrm{H}$ had acted in self-defence. If that had been the case, the city court found that his actions were not acceptable or proportionate in relation to the crime that had been committed. He was therefore convicted for causing bodily injury or illness (chapter 3 section 8 of the Penal Code).

Just like the city court, the Court of Appeal found that this was not a self-defence situation. However, unlike the city court, the Court of Appeal found that $\mathrm{H}$ had had the right to arrest $J$ as he caught him while $J$ was running from the scene of the crime but that the violence used to arrest him was disproportionate in relation to the crime. The Court of Appeal found that the circumstances were not such that the rules on excess were applicable and therefore convicted him just like the city court had.

The majority of the Supreme Court (3 out of 5 Justices) acquitted H of causing bodily injury or illness. According to them, this was a self-defence situation as it was just a matter of minutes between when the theft was committed and when $\mathrm{H}$ started to follow $\mathrm{J}$; by starting to run $\mathrm{J}$ had "obstructed the repossession of property when caught in the act" (chapter 24 section 1 of the Penal Code, see above) according to the Court. The two questions which the Court then answers are whether or not Hs actions were clearly unjustifiable, and if so, if it was a case of excessive self-defence. The Court found that the circumstances of the case were such that Hs actions were clearly unjustifiable as he had used a lethal weapon in a situation which was not very threatening to him. Nevertheless, the majority of the Supreme Court found that this was a case of excessive self-defence, based on the way the defendant had experienced the whole situation; that he was abruptly awoken and upset because of what had been done to his new car. H was therefore acquitted. The minority of the Court (2 out of 5 Justices) agreed with the majority on everything apart from their assessment of the question of excessive selfdefence. In their dissenting opinion they stated that they found it understandable that $\mathrm{H}$ was upset and angry but that the value of the stolen goods combined with the fact that $\mathrm{H}$ was not attacked by $\mathrm{J}$ but rather attacked him did not allow for $\mathrm{H}$ to be exempted from responsibility. The Justices of the Supreme Court in this case are not disagreeing on how the law is to be interpreted when it comes to self-defence. Where they do disagree is in assessing the defendant's thoughts and emotions in relation to his violent acts.

26 NJA 1994, 48. 
In the majority's grounds for acquittal, I identify two discourses which I argue relates to masculinities, violence and law. The first one is about nature and what can be seen as "natural". ${ }^{27}$ After describing the emotional state H was in, the Supreme Court proceeds by stating:

"It appears as natural that, in this situation, [H] did not think about putting the knife away when he caught up with [J]." 28

Why this appears as specifically "natural" is left unsaid. If the Court had said that it appeared as understandable or comprehensible that the defendant did not think about putting the knife away, it would have had other connotations than the use of the word "natural". To use the word "natural" implies that his not thinking about putting the knife away is related to his nature. Could this be further understood as telling us something about a certain view about the nature of men and masculinities? This reflects a preconception in society that it is "natural" that when a man becomes upset or angry, he responds violently.

I agree with Davies that the "natural" is not an apolitical concept and that

"it is a central part of many ideological systems to naturalise, or make normal, eternal and unchangeable certain fundamental aspects of their world view. "29

My point is not that the Supreme Court intentionally used the phrase natural to make an ideological cementation of its view of masculinity nor that the phrase was used with the purpose to hide underlying ideals of masculinity. But by using the phrase "natural", the Supreme Court contributes to a discourse which aims to uphold a clear distinction between nature and culture and in which what is named natural is also beyond question. By saying that it is natural that $\mathrm{H}$ forgot to put away the knife, it becomes more difficult to question his doing so. If the Court had used the word "understandable", it would be much easier to ask why.

Another discourse, related to the previous one, is a discourse on emotions. ${ }^{30}$ The following quote can serve as an example, where the Supreme Court uses the emotions of the defendant to explain and justify why this was a case of excessive self-defence:

"[H] was upset because of the damages done to the car he had just purchased with his savings of 90000 SEK. He should at the time have been still half asleep and has had difficulties in thinking on how to act." 31

27 Appealing to nature is a power strategy that can be revealed through discourse analysis as it can be used to include certain behaviors or identities et cetera and exclude others. See NiemiKiesiläinen/Honkatukia/Ruuskanen, Legal Texts as Discourses, in: Gunnarsson/Svensson/ Davies (eds.), 82.

28 NJA 1994, 48 (58), by own translation.

29 Davies, Taking the inside out: sex and gender in the legal subject, in: Naffine/Owens (eds.), Sexing the Subject of Law, The Law Book Company Ltd, Sydney 1997, 32.

30 On relations between emotions and responsibility in criminal law, see Burman, Blaming violent men - A challenge to Swedish criminal law on provocation, Women's Studies International Forum, 01/2014 as well as Burman, Provokation - förnuft eller känsla?, in: Träskman/ Andersson/Wong/Örnemark Hansen (eds.), Festskrift till Per Ole Träskman, Norstedts Juridik, Stockholm 2011.

31 NJA 1994, 48 (58), by own translation. 
What is striking here is the taken-for-granted-ness of it all. The Court does not discuss the reasonableness of his emotions in this situation and above all, does not question the way he acted because of them. This is connected to the nature discourse discussed above. According to Kahan and Nussbaum, a mechanic conception of emotions (against which they are critical) is linked to an idea of human nature - by and large emotions just happen to us whereas thoughts and ideas require more active involvement. ${ }^{32}$ In her research on emotions and the defence of provocation in Swedish criminal law, Burman finds that although Swedish criminal law does not go along with this mechanic conception of emotions it still has an ambivalent attitude towards it when it comes to the assessment of what the defendant did after the alleged provocation. ${ }^{33}$ She gives examples of how a more mechanic conception of emotions is represented in case-law as well as doctrine. The emotions of the perpetrator are regarded as entirely caused by the actions of the victim and, according to Burman,

"the perpetrator's own role in the creation and interpretation of the emotion is made invisible." 34

Although Burman is talking about provocation and the topic of this article is self-defence, the results of her research are still applicable here, as there are many similarities between the defences of provocation and of self-defence in relation to masculinities. Both defences concern men's responses to different kinds of attacks on and threats to their persons and the emotions connected to those responses. In the present case, the Supreme Court seems to find that the emotions of defendant (being upset, angry and even a bit confused because of being so abruptly awoken) just happened to him, not something he was a part of creating and then choosing to act upon. It is these emotions that just happened to him which cause the "natural" consequence that he forgot to put away the knife later on. The Court does not question if it is reasonable to get so angry and upset because of damages done to a car, and this hides Hs responsibility for his own emotions and how he handles them.

The quote from the written judgment also begs the question how important the fact that it was a brand new car was for the assessment of excessive self-defence which leads us to relations between men, masculinities and cars, but that is outside the scope of this article. $^{35}$

\section{Should I stay or should I go?}

The second case begins one late night in central Gothenburg. ${ }^{36}$ Two men ( $\mathrm{G}$ and $\mathrm{K}$ ) started quarrelling in a taxi queue until a taxi driver separated the two of them and they

32 Kahan/Nussbaum, Two conceptions of emotions in criminal law, Columbia Law Review, Vol. 96 (1996), 278-280.

33 Burman, 110-111.

34 Burman, 111, by own translation.

35 For an example of research on the relations between men, masculinities and cars, see Balkmar, On Men and Cars: An Ethnographic Study of Gendered, Risky and Dangerous Relations, Dis, Linköping University, Linköping 2012.

36 NJA 1999, 460. 
both went different ways. A short while later, $\mathrm{K}$ saw $\mathrm{G}$ in the queue again and $\mathrm{G}$ spat in $\mathrm{Ks}$ direction. They started quarreling and then $\mathrm{G}$ pushed $\mathrm{K}$ after which $\mathrm{K}$ was able to avoid being hit by Gs fist. In return, $\mathrm{K}$ hit $\mathrm{G}$ over the mouth with his own fist. The prosecutor pressed charges of assault (chapter 3 section 5 of the Penal Code) against K.

The city court convicted $\mathrm{K}$ of assault as he, according to the court, was not acting in self-defence, but rather responding to Gs provocation. He had without difficulty been able to fend off Gs punch at him and could also easily have left the place without any further trouble.

$\mathrm{K}$ appealed the conviction. The Court of Appeal acquitted him. Just like the city court they based their verdict on what $\mathrm{K}$ had said in his testimony, but unlike the city court found that despite Gs provocation $\mathrm{K}$ had been acting in self-defence. The fact that $\mathrm{K}$ could have left the location after $\mathrm{G}$ spat at him did not change the assessment of the justifiability of Ks acts. Neither was the violence in itself clearly unjustifiable. One Judge of Appeal, however, did not agree with the majority in their acquittal. In his dissenting opinion, he states that the right to defend one-self against an attack cannot include situations where both parties have provoked one another in a way which makes it clear for both of them that there is a risk that the provocations will turn into violence. He continues by saying that a person who chooses to continue with a "provoking argu$m e n t$ " instead of leaving the location can't claim self-defence when he responds to an attack that is a foreseeable consequence of his own actions. The dissenting Judge of Appeal agreed with the city court's verdict and found that $\mathrm{K}$ should be convicted of assault.

The Prosecutor-General appealed against the verdict but was unsuccessful as the Supreme Court agreed with the majority of the Court of Appeal and affirmed the acquittal. There was an initiated criminal attack against which $\mathrm{K}$ had a right to act in selfdefence. The Prosecutor-General claimed that the attack was over when K fended off Gs punch but the Supreme Court disagreed with that, stating that K acted in self-defence immediately after Gs punch. Regarding the justifiability of Ks actions, the Supreme Court refers to preparatory works and earlier case-law which states that a relatively wide margin of appreciation is to be granted to the defendant when it comes to the alternatives $\mathrm{s} /$ he had to avoid or avert the attack and concludes:

"Even if it would have been possible for [K] to leave the location after [G] tried to punch him, it cannot against that background be seen as clearly unjustifiable that [K] instead stayed and faced the attack. "37

The Supreme Court notes that the punch K gave G was hard and led to rather serious injuries but decides that it was just one punch and that $\mathrm{K}$ did not intend to cause such harm. The fact that G was physically bigger than K also led the Supreme Court to rule that Ks violent act was not clearly unjustifiable.

In the third case we have the defendant $\mathrm{D}$ who was charged with murder, alternatively gross assault and causing another's death. ${ }^{38}$ The victim, $Z$, had demanded that $\mathrm{D}$ paid him money to make up for spreading what $Z$ claimed to be false rumours about $Z$ (socalled "private fining"). According to the defendant, $Z$ had stolen different electronic 
goods from him, for example a TV-game. $Z$ had denied this. They had agreed to meet up and both men brought knives with them, and as soon as Z realised D wasn't going to pay, he attacked. Eventually, D had stabbed Z enough times so that he could get away, in total five times in the chest. $Z$ died moments after, due to his injuries.

D was prosecuted for murder (chapter 3 section 1 of the Penal Code) or alternatively gross assault and causing another's death (chapter 3 section 6 and section 7 of the Penal Code). The city court acquitted him as they found his actions were not clearly unjustifiable due to the circumstances of the situation. The defendant had, according to the city court, not been able to subdue the victim until the last stab with his knife and was therefore acting in self-defence. Regarding the justifiability, the city court found that $Z$ was physically bigger than $\mathrm{D}$ and had a criminal background which included violent crimes. The court also notes, that even if it is not permissible to carry a knife in public places, a person who is attacked with a knife is allowed to defend him- or herself with a knife. As the attack D faced was of a lethal kind, he had the right to defend himself in a way that would stop the attack.

A divided Court of Appeal acquitted him too; the majority found that although his actions were clearly unjustifiable the circumstances were such that this was to be considered excessive self-defence. Among these circumstances was the fact that there was grave danger, that the attack was sudden and that the whole course of events was very quick. Once again Zs physical size is mentioned, and also the fact that he had a higher status than D in criminal circles. One judge however, did not find the circumstances such and wanted to convict $\mathrm{D}$ for manslaughter. The minority found that both $\mathrm{D}$ and $\mathrm{Z}$ had been prepared and ready for a fight, so the attack couldn't have come as a surprise to $\mathrm{D}$ and his actions after the fight also suggested that this was not to be regarded as excessive self-defence.

Finally, a divided Supreme Court convicted D for manslaughter. The majority found that Ds actions were clearly unjustifiable, as he quite easily could have gotten away from the scene or called for help. As this was about lethal violence, the Supreme Court states that there must be higher demands on there not being any alternatives to that form of violence for it to be regarded as not clearly unjustifiable, referring to article 2 of the European Convention for the Protection of Human Rights and Fundamental Freedoms (the right to life). The fight took place in the middle of the day, close to a residential area. As D was prepared for a fight, and had in between the stabs paused to look upon the victim, the circumstances couldn't be regarded as such that excessive self-defence was in question.

The minority (two Justices of the Supreme Court) wanted to acquit him as they found it unreasonable to demand of him to get away from the scene as it would have been difficult for $\mathrm{D}$ to escape from the location, and they also found that it could not have been demanded of $D$ to use less violence to avert the attack due to his young age, inexperience and also the fact that $\mathrm{Z}$ was bigger than him.

The following two quotes demonstrate how the Court reasons about the kind of violence that the defendant used and also what kind of demands that could be put on him to leave the location:

"It must, despite the margin of appreciation to the advantage of the defendant that the preparatory works speak of, with the use of lethal violence come high demands 
on that there has been no alternative to warding off the attack for the violence to not be seen as clearly unjustifiable (cf. article 2 of the European Convention for the Protection of Human Rights and Fundamental Freedoms). "39

"Further, a comparison between [Ds] and [Zs] injuries, as well as [Ds] statement that he held [Zs] knife-arm while the stabs were dealt out, strongly speaks against that [D] was in such a disadvantageous position that it was necessary to use lethal violence rather than to respond to [Zs] attack in a for him less devastating manner and after that leave the location. "40

After having found that Ds actions were clearly unjustifiable, the Court moves on to discuss the issue of excessive self-defence. This becomes a question about preparation and time:

"[D] has said that the purpose of the meeting was to discuss the private fining and that he was prepared that [Z] could become physically violent as he could not pay. [D] was consequently not entirely unprepared for an attack. The circumstance that he had the knife easily accessible speaks in the same direction. The course of events was not entirely of a short duration and [D] has stated that he after every stab looked at [Z] to see if the stab had had effect. It has therefore been time for consideration." 41

When looking at the two cases we can see similarities as well as differences. They both concern a couple of young men who are more or less prepared for, or willing to, fight one another. A key issue in both cases is, if the defendant could be expected to leave the location or find another alternative to the violence he used. Simultaneously, I want to argue that the cases also concern expectations on men to stay and be able to defend themselves. This is a clear example of how relations between masculinity norms and violence play a role in the application of law. In the second case, the majority of the Supreme Court found, that it could be expected of D to leave the location instead of acting in self-defence, but it is arguable that masculinity norms expected him to stay and defend himself. Defining masculinity as heroism, Whitehead argues that a way of achieving masculinity is for a man to overcome his fear in the face of danger and that the fear of not being able to do so (so-called Masculine Anxiety] can lead to conflict and violence. ${ }^{42}$ From that point of view it is possible, that $\mathrm{D}$ could or would not leave the location because that would mean that he would fail to prove himself a man, he would become a Non-Man. ${ }^{43}$ Drawing on Whitehead (among others), Andersson shows how the phrase "sissy" is used in a heroic discourse on violence as a way of constructing masculinity by pointing out that those boys or men who are not willing or ready to defend

39 NJA 2005, 237 (248), by own translation.

40 NJA 2005, 237 (248), by own translation.

41 NJA 2005, 237 (249), by own translation.

42 Whitehead, Man to Man Violence: How Masculinity May Work as a Dynamic Risk Factor, The Howard Journal, Vol. 44 No. 4 (2005), 411-422.

43 See Whitehead, 416-417 concerning the positions of the Hero, the Villain and the Non-Man and how they relate to violence. 
themselves by means of violence are "sissies", they fail to achieve or prove their masculinity. ${ }^{44}$

In the same way that these masculinity norms - to be able to overcome fear and to be able to defend oneself, with violence if necessary - could have hindered D from living up to the majority of the Court's expectation on him to leave, the same norms can also play a part in the Court not expecting a defendant to leave. I find the case from 1999 to be an example of this. Referring to the same margin of appreciation found in the preparatory works, a unanimous Supreme Court comes to the opposite conclusion compared to the conclusion of the majority in the case from 2005. Even though it was possible for $\mathrm{K}$ to leave in that case after $\mathrm{G}$ spat at him, it was not clearly unjustifiable to stay, he was not expected to leave. I argue that these masculinity norms make it intelligible and understandable for the Court that $\mathrm{K}$ chose to stay and respond to the insult. Referring back to the previous discussion on the phrase "natural"; to stay and fight might also be a "natural" thing to do.

So how come the different outcomes in these two quite similar cases? Why is one expected to leave and the other is not? Answers can be found in the contexts of the cases. An obvious difference between the two cases, is the kind of violence in question and the consequences of the violence. In the second case the violence is lethal; Ds violence leads to Zs death. D is convicted of manslaughter. In the first case it's just one blow, although it caused relatively severe injuries. $\mathrm{K}$ is acquitted of assault. When dealing with issues of law and violence, it is important to take the kind of violence into consideration as law does not treat different kinds of violence in the same way.

However, it is not only the kind of violence which is important to consider, but also by whom it is committed. The defendants in the cases are both young (16 and 19 years old respectively, at the time of the events in question), but whereas K (16 years old) had no criminal record and according to the verdict in the city court, lives under socially well-adjusted conditions, D (19 years old) is, as far as can be understood from the verdict, part of criminal circles. Can it be so that D is seen by the Court as a "tough guy" who should not be afraid in these kinds of situations, that he should be able to handle the situation? As the next case is going to show, the Court's assessment can be quite different when another kind of masculinity is ascribed to or represented by the defendant. Masculinities do not relate to violence in the same way, as was mentioned in the introduction, and therefore self-defence legislation does not apply in the same way to different kinds of masculinities. Norms and preconceptions related to different kinds of masculinities play a part of the assessment of the act in self-defence and the justifiability of it as well as a part of the assessment of excessive self-defence.

The title of this chapter is a question: "should I stay or should I go?", and this has also been the question discussed in the chapter: expectations on male defendants, based on legal as well as gender norms, to stay or go in self-defence contexts. It has been suggested and will be further elaborated upon in the conclusion that these norms interact, and that the outcome of these interactions varies, depending on what kinds of masculinities are in question. This brings us to the next case.

44 Andersson, Constructing young masculinity: a case study of heroic discourse on violence, Discourse \& Society, Vol. 19 (2/2008), 139-161. 


\section{It's all relational}

The last case $\mathrm{e}^{45}$ takes place in a rural area south of Stockholm. H was prosecuted for gross assault against a neighbour, $\mathrm{W}$. The day before the event occurred, $\mathrm{W}$ had threatened $\mathrm{H}$ and his family. This had scared them a lot and they had decided to move. On the day in question, W came to Hs house when he was home alone with his children. W was making threats. $\mathrm{H}$ confronted him and finally hit him in the head with a hammer. Then he went back inside to see to his children and to call the police. Back outside he saw that $\mathrm{W}$ was limping around on the grounds and making strange noises and then $\mathrm{W}$ was charging against him. This time, $\mathrm{H}$ hit him a number of times in the head with his hammer, harder than before. When the police came, $\mathrm{W}$ had obtained severe injuries. $\mathrm{H}$ and his family had been warned by other neighbours that $\mathrm{W}$ was violent and threatening before moving in but had not until that point had any problems with him.

The city court convicted $\mathrm{H}$ of gross assault as it found that the second attack with the hammer was clearly unjustifiable, and that he had had time to think when he went back inside after the first round, finding that this was not a case of excessive self-defence. The city court stated that his state of mind made it difficult for him to assess the situation and for example hit W less gravely. However, continued the city court, these difficulties had not been severe enough to justify that $\mathrm{H}$ should be exempted from responsibility.

In the Court of Appeal, a psychologist testified on Hs request, in support for seeing Hs actions as excessive self-defence. Nevertheless, the Court of Appeal affirmed the city court's judgment.

The Supreme Court, on the other hand, acquitted H, as they found the circumstances such that this was a case of excessive self-defence, not because he hadn't had time to think on what to do but because of his psychological condition. He was very afraid since the events of the day before and now W showed up right outside his front door. This led, according to the majority of the Supreme Court, to such a stressful situation that Hs actions must be regarded as excessive self-defence. One Justice was of a different opinion. He found that the defendant had had both the time and the ability to choose less severe violent actions and therefore should be convicted for gross assault.

The following quote can be found in the verdict from the Supreme Court, and in this quote the Court discursively constructs $\mathrm{H}$ and $\mathrm{W}$ as representing two different kinds of masculinities and compares them to each other:

"[H] was at the time 40 years of age. He was and is still unpunished. He has, without any objections having been raised against this, during this case been called a man of peace. [W] on the other hand had when these events occurred a documented past with not only substantial controversies with neighbours but also incidents reported to the police and convictions regarding threats and violence." 46

As far as we can understand from the case, we have $\mathrm{H}$ who seems to be a middle-class family man with good social relations and an established position in society. H therefore lives up to many traditional and normative ideals of masculinity. $\mathrm{W}$ on the other hand has a criminal record, seems to be a loner, and has bad relations with his neighbours.

45 NJA 2009, 234.

46 NJA 2009, 234 (242), by own translation. 
This quote is a single paragraph that stands for itself when the Supreme Court assesses the situation and it is not spelled out in the verdict what impact it has on the outcome of the case, and if so how. However, it hints at the possibility that being "a man of peace" has been an advantage to $\mathrm{H}$ at the same time as Ws criminal background has been a disadvantage to $\mathrm{W}$. As has been mentioned in the introduction, gender, and therefore masculinities, is relational - always constructed or defined in relation to something else. In this case two different kinds of masculinities can be defined, and they can only be defined in relation to each other. To be a "man of peace" is an advantage to $\mathrm{H}$ just because $\mathrm{W}$ apparently is not. This raises the question whether or not the grounds for the Court's decision would have looked different if $\mathrm{W}$ had been a "normal" middle-class family man, too, or if $\mathrm{H}$ had been a loner with a criminal past.

Looking back at the previous case, where $\mathrm{D}$ stabbed $\mathrm{Z}$ five times in the chest which led to the latter's death, the Court found that the pauses between the stabs were enough time for consideration, which contributed to the conclusion that it was not a case of excessive self-defence. I suggested then that the kind of masculinity that D represents in the case could have played a part in this assessment: a tough guy from criminal circles shouldn't be so afraid in these kinds of situations that excessive self-defence could come in question. In this case however, $\mathrm{H}$ goes inside, checks that his children are alright and calls the police in between the two self-defence situations. The Supreme Court finds that this gave him time to consider what to do but find that he was so afraid that this was a case of excessive self-defence. The kind of masculinity he represented allowed for him to be that afraid, he didn't need to be able to handle it in the way D from the other case had to.

\section{Discussion}

The theme of this special issue is violence and law. As the right to, use of, and punishment for violent acts are regulated by law, as well as the application of law, it is crucial to make visible and scrutinise how this happens. What kind of violence - in relation to perpetrator, victim or context - is allowed, justified or condemned? The focal point of this article has been masculinities, men's violent acts and the right to self-defence in Swedish criminal law. Self-defence is a particularly interesting context to look at when studying relations between masculinities, violence and law as acts that would otherwise be considered criminal in certain circumstances are deemed justifiable and sometimes when these acts in self-defence cannot be justified, they can still be deemed excusable. The assessment of the justifiability or the ability to excuse men's violent acts is open to the influence of masculinity norms and ideals.

The identified discourses have been sorted into three different themes: "a natural thing to do", "should I stay or should I go?" and "it's all relational". These themes all relate to expectations on men and to masculinity norms and ideals. The analysis has shown how appeals to nature, and perhaps the "nature" of men, have been made to make intelligible and to justify men's violent acts. Other gender norms, such as the expectation on men to be able to defend themselves and others as well not having to take personal insults without responding to them have also been revealed in the cases and their interaction with the rules of self-defence. In this way, I argue, the legal construction of self- 
defence and the application of it contributes to the normalisation of men's violence. Feminist legal scholars have repeatedly shown how legal constructions of self-defence are typically based on male experiences of violent situations. ${ }^{47}$ Legal constructions of self-defence usually presume two persons of fairly equal physical strength involved, but this is seldom the case when women use violence in self-defence.

In the second case, these masculinity norms played a role in justifying $\mathrm{K}$ hitting $\mathrm{G}$ after their quarrel in the taxi queue, he was not obliged to leave in the eyes of the Supreme Court (although in the Court of Appeal a dissenting judge found that he was obliged to do so). However, in the third case, the majority of the Supreme Court found that it could have been expected of $\mathrm{D}$ to leave the location rather than stabbing $\mathrm{Z}$ (whereas the dissenting Justices found that he could not be expected to do so). As has been mentioned, this highlights the importance of remembering that men as well as masculinities are in relation to each other, and that other structures of power such as class, ethnicity, et cetera must be taken into account when discussing the relationships between masculinities, violence and law. The fourth case is a good example of this as well, as the defendant and the victim clearly had different social status in relation to one another.

Law's relation to masculinities and violence is not a straight-forward thing. The fact that there were, at some level throughout the cases and quite often in the Supreme Court, dissenting opinions in all of the analysed cases testifies to this. To analyse the justifiability of a self-defence act in a way involves leaving the study of the letter of the law and to use other tools, such as knowledge, "common sense" and norms and preconceptions to reach a conclusion. This gives room for gender norms to have an impact on the decision. What follows is an interaction; gender norms do have an impact on what happens in the criminal justice system and in criminal law but on the same time the criminal justice system and criminal law have an impact on gender norms.

The conclusion is, that when looking at the relationships between masculinities, violence and law, the open-endedness of law is highlighted. Law is not a closed system and the outcome of a case is never given, even when the circumstances are similar. The importance of studying law in its contexts cannot be stressed enough as these contexts are decisive. While law's open-endedness leads to uncertainty and unpredictability it also entails that law is an arena for struggle and change. Law can be used to maintain and confirm gender norms and gender relations but it can also be a tool to change gender norms and gender relations. If law can be used to condone men's violent acts and make them intelligible and normal it can also be used as a tool for breaking the bonds between masculinities and violence and change men's violent practices. When gender norms change, so will the practices that are condoned by those norms, and law can play a part in that change.

47 E.g. Wallace, Beyond Imminence: Evolving International Law and Battered Women's Right to Self-Defense, The University of Chicago Law Review, Vol. 71, No. 4 (2004), 1749-1781 and $\mathrm{McC}$ Colgan, General Defences, in: Nicholson/Donald/Bibbings (eds.), Feminist Perspectives on Criminal Law, Cavendish, London 2000, 152-155. 